\title{
KESABARAN ISTRI POLIGAMI
}

\author{
Muhammad Ali Rohmad \\ Universitas Islam Majapabit Mojokerto \\ alirohmad86@gmail.com
}

\begin{abstract}
The purpose of this research is to know about the conflict in family life, especially in family that the husband merried again (poligamy). Then patience poligamy wife is very interesting to research. This research used qualitative research methods. This research was done in Mojokerto by using the method of observation and interviews. Based on this study it can be explained that poligamy wives patience can be grouped into two reasons, namely the worldly reason, and the eschatological matters reason. The worldly reason include biological, economic, and social. Whereas eschatological matters include factors faith and worship.
\end{abstract}

Keyword: conflict, patient, poligamy

\begin{abstract}
Abstrak
Penelitian ini bertujuan untuk mengetahui lebih jauh konflik yang terjadi dalam kehidupan berumah tangga khususnya keluarga yang suami menikah lagi (poligami). Maka kesabaran istri yang dipoligami sangat menarik untuk diteliti. Penelitian ini menggunakan metode penelitian kualitatif. Penelitian ini dilakukan di Mojokerto dengan menggunakan cara pengambilan subyek secara purposive sampling, dan dalam menperoleh data menggunakan metode observasi dan wawancara. Berdasarkan penelitian ini dapat dijelaskan bahwa kesabaran istri yang dipoligami dapat dikelompokkan menjadi dua alasan, yakni alasan duniawi dan alasan ukhrowi. Alasan duniawi ini meliputi faktor biologis, ekonomi, dan sosial. Sedangkan ukhrowi meliputi faktor keimanan, dan ibadah.
\end{abstract}

Kata kunci: konflik, sabar, poligami

ISSN 2527-8401 (p) 2527-838X (e)

(C) 2016 JISH Pascasarjana UIN Walisongo Semarang

http://journal.walisongo.ac.id/index.php/jish 


\section{Pendahuluan}

Perjalanan manusia hidup di dunia ini senantiasa diwarnai dengan problematika dan konflik kehidupan yang silih berganti. Berbagai macam problematika tersebut pada hakikatnya sebagai ujian bagi manusia itu sendiri. Kesiapan dan ketangguhan fisik, mental, intelektual dan emosi sangat diperlukan agar seseorang dapat hidup bahagia dunia akhirat, sedang kelemahan dan kerapuhan pada segisegi tersebut akan membawanya ke dalam kenistaan, kesengsaraan dan kecemasan. ${ }^{1}$

Setiap orang pernah mendapatkan ujian atau musibah. Kebanyakan manusia cenderung menganggap bahwa cobaan atau ujian hidup terbatas pada hal-hal yang tidak menyenangkan, seperti bencana alam, merugi, kesedihan, sakit, kecelakaan, kematian atau hal-hal yang lazim disebut musibah. Paling tidak, nasihat untuk bersabar dan tabah menghadapi cobaan hidup umumnya dikemukakan pada saat-saat seseorang menghadapi masalah-masalah yang dirasa menyakitkan.

Walaupun manusia diciptakan oleh Allah dalam bentuk sebaikbaiknya, namun tidak berarti kehidupan manusia selamanya mulus tanpa rintangan, kesulitan, dan kegagalan (akan mendapat ujian). ${ }^{2}$ Manusia juga bisa susah, gelisah, cemas, dan lain sebagainya karena manusia juga diciptakan berada dalam susah payah serta berkeluh kesah dan kikir. Untuk menjawab segala masalah tadi, agama sudah memberikan resep untuk dapat bertahan dalam segala keadaan yakni dengan sabar. Adanya ujian dan perintah sabar dalam Al-Qur'an memberikan suatu indikasi bahwa dalam kehidupan manusia tidak luput dari hal-hal yang perlu disikapi dengan sabar, karena sabar adalah salah satu dari akhlak mahmudah. ${ }^{3}$

Adanya ujian dan perintah sabar dalam Al-Qur'an memberikan suatu indikasi bahwa dalam kehidupan manusia tidak luput dari hal-

${ }^{1}$ Aunur Rahim Faqih, Bimbingan Dan Konseling Dalam Islam, (Yogyakarta: UII Press, 2001), hlm. 2

2 Hanna Djumhana Bastaman, Integrasi Psikologi dengan Islam (Menuju Psikologi Islam), (Yogyakarta: Pustaka Pelajar, 1995), hlm. 55

${ }^{3}$ Humaidi Tatapangarsa, Akhlak Yang Mulia, Bina Ilmu, Surabaya, Hal. 145. 
hal yang perlu disikapi dengan sabar. Musibah adalah salah satu ujian dari dianggap sebagai sesuatu yang tidak menyenangkan, maka keberadaannya harus diterima dengan kesabaran. Islam tidak menginginkan orang yang sabar di saat terkena musibah menjadi pasif, hanya diam, pasrah begitu saja dan sebagainya, namun sikap tersebut harus didasari dengan usaha dan upaya terlebih dahulu.

Dalam kehidupan keluarga dan berumah tangga kesabaran harus dimiliki oleh seorang suami, istri, bahkan anak. Suami sabar dalam mencari nafkah untuk keluarga. Istri sabar dalam taat/melayani suami, memelihara anak dan rumah tangga. Anak sabar dalam taat dan patuh kepada kedua orang tua. Semua harus saling menjaga tugas dan fungsinya masing-masing dengan kesabaran.

Ujian hidup dalam perjalanan berumah tangga sering kali diterpa konflik, salah satu bentuk konflik yang sering kita jumpai adalah saat suami menikah lagi sehingga istri mempunyai 'madu' dan merasa cintanya terbagi. Banyak penelitian yang mengungkap konflik poligami dari sisi suami, namun jarang sekali yang mengungkap konflik atau masalah yang dirasakan oleh istri poligami. Modal utama istri yang dipoligami adalah sabar. Tanpa kesabaran, mustahil rumah tangga pernikahan poligami dapat berjalan dengan baik.

\section{Konsep Sabar dan Aplikasinya}

Sabar berasal dari kata (صبر) bersabar (يصبر) tabah hati (صبار) berani (atas sesuatu). ${ }^{4}$ Secara etimologi sabar berarti menahan dan mengekang. Selanjutnya dijelaskan setiap orang yang menahan terhadap sesuatu dinamakan sebagai sabar. Secara terminologi sabar berarti menahan dari segala sesuatu yang tidak disukai karena mengharapkan ridha Allah. Sedangkan secara istilah sabar adalah ketabahan hati dalam menanggung berbagai macam kesulitan dalam hal mencegah perbuatan-perbuatan maksiat. Dalam pandangan Ibnu Qayyim Al- Jauziyah, sabar adalah menahan jiwa dari cemas, lisan dari mengeluh, dan organ tubuh dari menampar pipi, merobek-robek

\footnotetext{
${ }^{4}$ Mas'ud Hasan Abdul Qohar, Kamus Ilmiah Populer, (Jakarta: Bintang Pelajar, tt), hlm. 184
} 
baju dan seterusnya. ${ }^{5}$ Dalam pandangan Yusuf Qordhowi, sabar yaitu menahan dan mencegah diri dari hal-hal yang dimurkai Allah swt. dengan tujuan semata-mata mencari keridhoan-Nya. ${ }^{6}$

Dalam kamus besar Bahasa Indonesia, sabar diartikan sebagai tahan menghadapi cobaan, dalam hal ini sabar sama halnya dengan tabah. $^{7}$ Al-Maraghi mengungkapkan bahwa sabar adalah ketabahan hati dalam menanggung berbagai macam kesulitan sebagai upaya mencegah perbuatan-perbuatan yang tidak disukai dan dalam rangka melaksanakan ibadah, serta ketabahan dalam menjauhi perbuatanperbuatan maksiat. ${ }^{8}$ Sabar juga diartikan sebagai keteguhan hati dalam menghadapi kesulitan dan bahaya atau keteguhan hati dalam rangka memperoleh kelapangan dan kecukupan hidup, sehingga dimanifestasikan dalam bentuk pekerjaan dan perjuangan. ${ }^{9}$ Imam alGhazali menjelaskan bahwa sabar merupakan gambaran kokohnya dorongan agama seseorang dalam menghadapi syahwat dan menaklukkan syahwat lalu menentangnya. ${ }^{10}$

Sabar banyak sekali dijelaskan dalam Al Qur'an, ditemukan empat puluh enam ayat yang memuat kata sabar dan sembilan belas ayat memuat kata kesabaran, ${ }^{11}$ di antaranya seperti yang disebutkan pada surat Al-Baqarah ayat 153,155,156, dan 157 yang bila dipahami dan diikuti dengan seksama akan membawa kepada ketentraman dan sekaligus dinamika hidup. ${ }^{12}$ Orang yang sabar akan terhindar dari

\footnotetext{
5 Ibnu Qayyim Al-Jauziyah, Sabar Perisai Seorang Mukmin, terj. Fadli, (Jakarta: Pustaka Azzam, 2002), hlm. 12

${ }^{6}$ Yusuf Al-Qordhowi, Al-Qur'an Menyurub Kita Sabar, terj. Abdul Azis Salim Basyarahil, (Jakarta: Gema Insani Press, 2006), hlm. 12

${ }^{7}$ Depdikbud, Kamus Besar Bahasa Indonesia, (Jakarta: Balai Pustaka, 1990), hlm. 763

${ }^{8}$ Ahmad Musthafa Al-Maraghi, Tafsir al-Maraghi, terj. Bahran Abu Bakar, dkk. (Semarang: Toha Putra, 1992) hlm. 10

${ }^{9}$ Fachruddin, Ensiklopedi Al-Qur'an, (Jakarta: Rineka Cipta, jil. II, cet. I, 1992), hlm. 248

${ }^{10}$ Imam Abu Hamid al-Ghazali, Ringkasan Ihya' 'Ulum al-Din, terj. Labib MZ, 2004, Bintang Usaha, Surabaya, Hal. 222.

11 Subandi, Sabar: Sebuah Konsep Psikologi, 2011, Jurnal Psikologi UGM, Yogyakarta, Hal. 218.

12 Yusuf Al-Qordhowi, Bagaimana Memahami Syariat Islam, terj. Nabhani Idris, (Jakarta: Islamuna Press, 2002), hlm. 27
} 
kegelisahan dan terlindung dari berbagai gangguan kejiwaan. ${ }^{13}$ Adapun macam-macam sabar sebagai berikut:

1. Sabar terhadap musibah dan cobaan

2. Sabar dalam mematuhi perintah Allah

3. Sabar terhadap syahwat dan maksiat

4. Sabar atas celaan (selama berada dijalan Allah)

Selanjutnya Al-Jauziyah juga membagi konsep sabar menjadi beberapa kategori. Pertama, berdasarkan bentuknya (kesabaran jasmani dan rohani). Kedua, berdasarkan obyek (menerima perintah, menjauhi larangan, dan menerima takdir). Ketiga, berdasarkan hukumnya (wajib, sunnah, haram, makruh, dan mubah). ${ }^{14}$

\section{Poligami dan Problematikanya}

Kata-kata poligami berasal dari bahasa Yunani, yaitu dari kata polus yang berarti banyak dan gomus yang berarti perkawinan. ${ }^{15}$ Sedangkan Poligami dalam bahasa Indonesia adalah seorang laki-laki yang beristri lebih dari satu. ${ }^{16}$ M.Quraish Shihab berkomentar bahwa poligami adalah pintu darurat yang hanya bisa dibuka apabila ada keadaan yang darurat dan sangat mendesak. Sedangkan menurut Ibn Katsir, poligami adalah sesuatu yang diperbolehkan dalam agama dan berlaku hanya dalam kondisi-kondisi tertentu. ${ }^{17}$

Poligami merupakan salah satu tema penting yang mendapat perhatian khusus dari Allah swt. Dalam membahas masalah poligami ini kita tidak bisa lepas dari masalah anak-anak yatim, karena dalam ayat yang digunakan sebagai dasar utama tentang masalah poligami ini didahului dengan menerangkan masalah anak-anak yatim, dan Hal. 472

${ }^{13}$ M. Usman Najati, Psikologi dalam AlQur'an, Pustaka Setia, Bandung, 2005,

${ }^{14}$ Ibnu Q. Al Jauziyah, Indabnya Sabar, Terj. A.M. Halim, 2010, Maghfirah Pustaka, Jakarta. hlm 2

15 Istibsyaroh, Poligami dalam Cita dan Fakta, (Jakarta: Mizan Publika, 2004),

16 Ananda Santoso, Kamus Lengkap Bahasa Indonesia, (Jakarta: UI Press, 1998), hlm 219

17 Tim penyusun, Terjemah Tafsir Ibn Katsir jilid 2, (Surabaya: Al Hidayah, 2002), hlm 267

Vol. 1, No. 1 (2016) 
masalah anak yatim ini adalah berhubungan sebab akibat dengan masalah poligami, sebagaimana yang telah disebutkan oleh Allah dalam bingkai redaksi surat an-Nisa' ayat 3 dan ayat-ayat yang mendahuluinya.

Dalam an-Nisa' ayat 3, ayat ini dimulai dengan menerangkan tentang masalah anak yatim. Kata al-yatim sendiri dalam bahasa Arab dan Qur'an berarti seorang anak yang belum mencapai usia baligh yang telah kehilangan ayahnya, sementara ibunya masih hidup. ${ }^{18}$ Dari sini maka kita berhadapan dengan masalah anak-anak yatim yang telah kehilangan ayahnya, dimana Allah memerintahkan pada kita semua untuk berbuat adil dan baik kepada mereka, serta menjaga dan memelihara harta mereka dan menyerahkanya kembali kepada mereka ketika mereka telah menginjak usia dewasa. Jika ada kekhawatiran tidak terwujudnya keadilan kepada anak-anak yatim sesuai yang dimaksudkan, maka ayat di atas memperbolehkan poligami, yakni dengan menikahi ibu-ibu mereka yang telah menjanda. ${ }^{19}$

Konteks ayat yang memperbolehkan poligami ini sesungguhnya lebih ditujukan pada upaya menyelamatkan anak-anak yatim sehingga bisa hidup layak. Dengan demikian mengawini ibu dari anak yatim bukanlah tujuan utama, sehingga isu krusial dalam Al-Quran tentang masalah polgami adalah keadilan terhadap anak-anak yatim dari ibu yang dikawininya. ${ }^{20}$

Menurut al-Thobary, bagi laki-laki yang mempunyai keyakinan bahwa ia akan mampu berbuat adil ketika berpoligami, maka ia diperbolehkan berpoligami maksimal dengan empat orang wanita. Dan sebaliknya, laki-laki yang khawatir tidak akan dapat berlaku adil, maka ia cukup menikahi seorang wanita saja. ${ }^{21}$ Menurut Shahrur,

\footnotetext{
${ }^{18}$ M. Ali as-Shobuni, Rowai'ul Bayan Tafsir Ayatil Abkam Minal Qur'an, hlm 417

${ }^{19}$ M.Shahrur, Metodologi Fiqh Islam Kontemporer, penj. Sahiron Syamsuddin dan Burhanuddin, (Yogyakarta: eLSAQ Pres, 2004), hlm 430

${ }^{20}$ Kutbuddin Aibak, Kajian Figh Kontemporer, (Surabaya: eLKAF, 2006), hlm. 61

${ }^{21}$ Ibnu Jarir al-Thobary, Jami'al Bayan fi Tafsir al-Quran, juz 4, (Beirut: Dar al-Fikr), hlm. 155
} 
poligami hukumnya tidak hanya mubah, tetapi sangat di anjurkan, tapi dengan syarat (1) istri yang kedua, ketiga atau keempat adalah janda yang mempunyai anak yatim, (2) adanya kekhawatiran tidak dapat berbuat adil terhadap anak-anak yatim. ${ }^{22}$ Sehingga perintah poligami akan gugur jika tidak adanya salah satu dari kedua syarat tersebut.

Menurut Mustofa al-Maraghi, yang paling menjamin terwujudnya rumah tangga mawaddah wa rohmah adalah bila seorang suami memiliki seorang istri saja (monogami). Monogami merupakan jalan yang terbaik guna mewujudkan keluarga yang sakinah. Namun ketika dalam perjalananya ada halangan yang menghambat terwujudnya keluarga yang sakinah, maka di waktu itulah poligami di perbolehkan, bahkan di anjurkan karena itu adalah jalan yang lebih maslahat. Misalnya: si istri mandul, sedangkan si suami sangat menginginkan anak untuk melestarikan keturunannya, atau si istri adalah wanita yang "frigid" sedangkan yang laki-laki "perkasa". Dalam kasus-kasus yang seperti ini tidak ada alasan untuk melarang suami melakukan poligami. Dan tentunya poligami jauh lebih maslahah daripada menceraikan istri, atau bahkan berzina. ${ }^{23}$

Undang-undang di Indonesia, terdapat kurang lebih ada 5 pedoman sebagai peraturan tentang poligami yaitu UU No. 1 Tahun 1974, PP No. 9 Tahun 1975, PP No. 10 Tahun 1983, PP No. 45 Tahun 1990, dan Kompilasi Hukum Islam (KHI). Berdasarkan UU No. 1 tahun 1974 yang menyatakan bahwa sistem kekeluargaan yang dianut oleh Negara Indonesia adalah pernikahan yang monogini/monogami. Dalam undang-undang ini meskipun pada prinsipnya seseorang itu harus bermonogami/monogini akan tetapi pada penjelasan berikutnya memperbolehkan seseorang untuk berpoligami yaitu dengan ketentuan bahwa pengadilan dapat memberikan izin kepada suami untuk berpoligami dengan persetujuan pihak yang terkait.

${ }^{22}$ M. Shahrur, Metodologi Fiqh Islam Kontemporer, penj. Sahiron Syamsuddin dan Burhanuddin... hlm 430

${ }^{23}$ Abu Yasid, Fiqh Realitas, Respon Terhadap Wacana Hukum Islam Kontempore, (Yogyakarta: Pustaka pelajar, 2005), hlm 354 
Dalam KHI menyantumkan bahwa pihak pengadilan memberikan ketentuan yang sangat ketat bagi suami yang menginginkan poligami. Pertimbangan pengadilan tidak hanya masalah materi yang dinilai cukup untuk beristri lebih dari satu melainkan ada pertimbangan yang mendasar yaitu kemampuan suami untuk berlaku adil. Untuk itulah masalah poligami jelas yang menjadi kebijakan adalah para hakim di pengadilan agama. Sebisa mungkin kebijakan yang diterapkan mampu menjaga hak dan kewajiban suami dan istri.

Kebolehan poligami hanya merupakan solusi ketika tujuan dari perkawinan sudah tidak terpenuhi. Poligami tidak dapat dijadikan sebagai ajang mengumbar hawa nafsu, apalagi di jadikan cita-cita hidup. Dengan demikian, asalkan ada tujuan kemaslahatan, disamping itu kesejahteraan dan kerukunan rumah tangga terpenuhi, tidak sampai menimbulkan terlantarnya istri tertua, dan juga anakanaknya, maka poligami bisa dilaksanakan. Dengan bahasa lain, pintu poligami dalam Islam tertutup, tetapi tidak dikunci. ${ }^{24}$

\section{Metode Penelitian}

Penelitian ini menggunakan metode penelitian kualitatif, dengan alasan mengingat pada keunikan kasus yang hendak diteliti sementara hasil penelitian tidak dapat digeneralisasikan pada subyek lain pada populasi yang berbeda sehingga kasus tersebut membutuhkan pemahaman secara lebih mendalam, yang mana hal ini tidak dapat diperoleh melalui penelitian dengan metode kuantitatif, yakni perolehan data melalui prosedur statistik atau bentuk hitungan lainnya.

Adapun rancangan dalam penelitian kualitatif ini adalah termasuk ke dalam rancangan penelitian lapangan (field research), yaitu suatu rancangan penelitian yang dilakukan untuk memperoleh pengertian secara mendalam mengenai situasi dan makna sesuatu atau subyek yang diteliti. Penelitian ini dilakukan di Mojokerto. Peneliti menggunakan cara pengambilan subyek secara purposive sampling karena adanya pemilihan subjek penelitian yang dilakukan

${ }^{24}$ Ibid... Hlm 355 
dan ketersediaan subjek yang terbatas. Pengambilan subyek dilakukan berdasarkan kebutuhan peneliti dengan meminta informasi pada orang yang dianggap tahu dan telah dihubungi sebelumnya. ${ }^{25}$

Adapun ciri-ciri subyek penelitian adalah: (1) Perempuan yang telah menikah dalam sebuah praktik pernikahan poligami, baik yang berstatus sebagai istri pertama maupun sebagai istri kedua, dan seterusnya; (2) Beragama Islam; (3) Mampu berkomunikasi secara verbaI; (4) Bertempat tinggal di Mojokerto. Dalam memperoleh data dalam penelitian ini adalah dengan menggunakan metode observasi dan wawancara.

\section{Hasil Temuan Data}

Adapun hasil temuan data subjek penelitian dilapangan secara singkat sebagai berikut: Subjek pertama; adalah Istri kedua seorang Kepala KUA serta Dosen (istri pertama tahu dan mengizinkan). Sabar karena menganggap suami mampu berbuat adil, memiliki kecukupan ekonomi, dan diawal pernikahan merasa tidak akan ada masalah karena istri pertama tahu. Namun disamping itu tetap saja kadang tidak percaya diri saat bertemu dengan masyarakat luas. Subjek kedua; adalah Istri ketiga seorang Kyai, dimana istri pertama tahu tetapi tidak mengizinkan. Sabar dengan terpaksa karena menganggap suami memiliki ilmu yang tinggi, ekonomi yang mapan, sehingga menjadi suami Kyai adalah sebuah kebanggaan. Tidak ada rasa sungkan saat tampil di depan publik, seperti saat memberikan ceramah agama. Subjek ketiga; adalab Istri kedua pengusaha (istri pertama tidak tahu). Sabar karena suami mampu memenuhi semua kebutuhan, mulai dari rumah, mobil, sepeda motor, perawatan kecantikan. Dalam berinteraksi dengan masyarakat, tidak mementingkan keberadaan suami, yang penting seluruh kebutuhan terpenuhi. Subjek keempat; adalah Istri kedua seorang biasa (miskin), orangnya tidak cantik dan istri pertama tidak tahu. Setelah sekian lama menunggu jodoh tak kunjung datang, sampai akhirnya datang seorang yang beristri yang belum punya anak, ingin menikahinya.

25 Poerwandari, E. E., 1998. Pendekatan Kualitatif dalam Penelitian Psikologi. Jakarta: LPSP3 UI. 
Harapan untuk memiliki anak juga cukup besar, maka karena itulah dia bersabar. Secara ekonomi memang tidak dapat diharapkan dari suami ini, maka istri kedua inipun harus bekerja sendiri. Namun semua subjek diatas mengakui bahwa kesabaran yang dilakukan sering karena keterpaksaan dan ketidakberdayaan, sehingga tidak jarang dalam menjalankan mahligai pernikahan sering diwarnai masalah dan konflik. ${ }^{\mathbf{2 6}}$

\section{Pembahasan}

Pernikahan atau perkawinan merupakan ikatan lahir batin antara seorang pria dengan seorang wanita sebagai suami istri dengan tujuan membentuk keluarga (rumah tangga) yang bahagia dan kekal berdasarkn ketuhanan Yang Maha Esa. Semua insan yang melakukan pernikahan pasti mengharapkan keluarga yang sakinah, mawaddah, warohmah. Keputusan untuk menikah atau melanjutkan hidup menuju jenjang perkawinan merupakan hal sulit dan menjadi pengalaman mendebarkan bagi individu yang mengalaminya. Namun dalam kenyataannnya, dalam menjalankan pernikahan pasti akan menemui konflik. Kehidupan berkeluarga mungkin akan diwarnai oleh permasalahan dan konflik pribadi. Salah satu konflik yang mungkin terjadi adalah ketika suami menikah lagi (poligami). Terdapat beberapa faktor lain yang menjadi sebab konflik dalam rumah tangga, disamping adanya kenyataan yang tidak sesuai dengan harapan pra-pernikahan. ${ }^{27}$

Kesediaan antar pasangan dalam berkomunikasi untuk saling memperhatikan merupakan hal yang tidak dapat dipungkiri dan hal yang penting bagi keberlangsungan interaksi antar pasangan. Montgomery mengungkapkan: "Quality communication is central to quality marriage". Sebaliknya, dapat ditambahkan pula bahwa kualitas perkawinan penting juga bagi kualitas komunikasi. ${ }^{28}$ Komunikasi di

26 Wawancara, Mei 2015

27 Muhyidin, M., 2003. Meraih Mahkota Pengantin, Kiat-Kiat Praktis Mendidik Istri dan Mengajar Suami. Jakaria: PT. Lentera Basritama.

28 Sadarjoen, S.S. 2005. Konflik Marital, Pemahaman Konseptual, Aktual dan Alternatif Solusinya. Bandung: PT Refika Aditama 
awal keputusan suami untuk berpoligami menentukan kelanjutan dari kualitas hubungan suami istri dalam membina rumah tangga, meskipun kesabaran istri bisa saja timbul karena terpaksa.

Selalu ada alasan bagi laki-laki untuk membenarkan keputusannya berpoligami. Terdapat beberapa alasan yang dikemukakan suami saat hasrat berpoligaminya semakin besar, diantaranya adalah: (a) Fisik pasangan tak lagi rupawan. Karena usia, fisik istri mengalami kemunduran ukuran keidealan. (b) Adanya keinginan untuk menolong. Sebagian laki-laki merasa perlu untuk menikah lagi karena beberapa alasan, salah satunya adalah untuk menolong perempuan yang hendak dinikahinya agar kehidupannya lebih baik. $^{29}$

Secara psikologis, sifat poligamis tidak banyak menimbulkan konflik batin pada pihak pria, akan tetapi secara praktis dalam kehidupan sehari-hari dan dalam lingkungan rumah tangga, pada umumnya senantiasa menimbulkan banyak protes pada pihak istri. Hal ini didasarkan pada alasan berikut: (1) Harga diri istri yang merasa dilanggar; (2) Dasar egoisme yang sehat dalam mencintai suaminya, sebab ia tidak ingin dimadu atau dibagi cintanya; dan (3) Atas kemurnian relasi perkawinan. ${ }^{30}$ Adanya keinginan mencintai tanpa ingin berbagi dengan perempuan lain, rasa cemburu juga banyak dipicu oleh ketidakadilan suami dalam pembagian hak-hak istri, yang mana suami memberikan pembagian yang berbeda antara istri yang satu dengan istri yang lain. Sementara pihak istri tidak bisa menerima kondisi tersebut karena merasa haknya diabaikan, sehingga menyebabkan istri melakukan suatu usaha untuk menuntut keadilan tersebut. ${ }^{31}$

Beberapa penyebab munculnya konflik dalam rumah tangga ta'addud (poligami) adalah suami tidak adil dalam melakukan pembagian hak-hak istri. Ditambah dengan kondisi anak-anak yang

${ }^{29}$ Koen, Z.. 2007. 40 Tanda dan 10 Alasan Laki-Laki Ingin Berpoligami. Yogyakarta: Penerbit Galang press.

${ }^{30}$ Davakisni, T. H, 2001. Psikologi Sosial. Malang: Penerbitan Universitas, Muhammadiyah Malang.

${ }^{31}$ Kartono, K, 1992. Psikologi Wanita. Bandung: Mandar Maju. 
mengalami kurangnya perhatian ayah. ${ }^{32}$ Dalam menghadapi konflikkonflik diatas, maka kesabaran istri poligami sangat diperlukan. Terlepas dari apakah alasan kesabaran itu karena alasan duniawi maupun sabar karena alasan ukhrowi. Tetapi yang jelas, kesabaran mereka diawali dari sebuah keterpaksaan. Mereka menyadari bahwa tidak banyak yang dapat dilakukan dalam menghadapi konflik diatas. Hanya kesabaranlah satu-satunya solusi paling efektif untuk menghadapi semua.

Kesabaran istri yang dipoligami dapat dikelompokkan menjadi dua alasan, yakni alasan duniawi dan alasan ukhrowi. Alasan duniawi ini meliputi faktor biologis, ekonomi, dan sosial. Sedangkan ukhrowi meliputi faktor keimanan, dan ibadah. Diakui atau tidak, alasanalasan tersebut muncul karena keterpaksaan. Mereka sadar bahwa ketika harapan hidup bahagia dengan keluarga tidak kunjung tercapai maka akan menjadi sumber stres yang sering menghasilkan perasaan kecewa, sakit hati dan kemarahan. Kesadaran atas resiko itulah, maka kesabaran sangat dibutuhkan seorang istri agar terhindar dari konflik yang berkepanjangan.

Keempat subyek memiliki alasan yang berbeda ketika menyatakan bersedia dipoligami. Kebanyakan yang menjadi pertimbangan awal adalah tentang kecukupan ekonomi. Besarnya biaya hidup untuk diri sendiri dan keluarga mengharuskan para subjek memenuhinya dengan berbagai cara. Pernikahan poligami memang menjadi suatu pernikahan yang sensitif dan mudah memicu terjadinya konflik, khususnya pada pihak perempuan yang dipoligami, baik berstatus sebagai istri pertama maupun istri kedua dan selanjutnya. Namun keempat subyek memiliki cara yang hampir sama dalam mengatasi problem pribadi dan konflik tersebut, yaitu dengan bersikap sabar dan mengembalikannya kepada Allah swt. termasuk juga dengan merujuk kepada syari'at Islam tentang poligami meskipun itu tidak mudah.

Salah satu sikap positif (khusnudhon) para subjek adalah keyakinan bahwa semua hal pasti memiliki sisi positif dan negatif,

32 Al-Hamd, M. 2004. Kesalahan-Kesalahan Suami. Surabaya: Pustaka Progressif. 
termasuk poligami. Manfaat yang bisa diambil dari adanya pernikahan poligami, diantaranya adalah mengatasi problem sosial yang salah satunya disebabkan oleh bertambahnya jumlah perempuan yang melebihi jumlah laki-laki. Selain itu juga untuk mengatasi problem pribadi yang salah satunya disebabkan oleh keadaan istri yang tidak mampu memiliki anak atau mandul. ${ }^{33}$ Konflik juga memiliki sisi baik, konflik digambarkan seperti lem yang menguatkan hubungan antar manusia, asal ditata dengan baik. Konflik bisa menjadi sebuah awal atau perantara menuju hubungan yang lebih baik dalam rumah tangga. Hal ini bergantung kepada strategi serta pengambilan cara yang tepat dalam mengatasi konflik tersebut, Terlebih apabila masing-masing pihak, baik istri pertama, 'madu' maupun suami benar-benar memahami poligami dari sisi positif dan negatifnya dengan tetap bersandar pada syari'at maka seburuk apapun dampak poligami pelakunya tetap dapat mengambil sisi maslahat-nya. ${ }^{34}$

\section{Kesimpulan}

Sabar merupakan salah satu akhlak terpuji. Sabar Secara etimologi berarti menahan dan mengekang. Secara terminologi sabar berarti menahan dari segala sesuatu yang tidak disukai karena mengharapkan ridha Allah swt. Sabar adalah lawan dari mengeluh. Adapun macam-macam sabar adalah; Sabar terhadap musibah dan cobaan; sabar dalam mematuhi perintah Allah swt; sabar terhadap syahwat dan maksiat; sabar atas celaan (selama berada dijalan Allah swt). Al Jauziyah juga membagi konsep sabar menjadi beberapa kategori. Pertama, berdasarkan bentuknya (kesabaran jasmani dan rohani). Kedua, berdasarkan obyek (sabar menerima perintah, menjauhi larangan, dan menerima takdir). Ketiga, berdasarkan hukumnya (sabar wajib, sunnah, haram, makruh, dan mubah).

${ }^{33}$ Mubarak, S. I.,2003. Poligami yang Didarnbakan Wanita. Bandung:Syaamil Cipta Media.

${ }^{34}$ Andayani, B., 2001. Marital Conflict Resolution of middle Class Javanese Couples, Australia: La Trobe University. 
Kesabaran istri yang dipoligami dapat dikelompokkan menjadi dua alasan, yakni alasan duniawi dan alasan ukhrowi. Alasan duniawi ini meliputi faktor biologis, ekonomi, dan sosial. Sedangkan ukhrowi meliputi faktor keimanan, dan ibadah. Namun kebanyakan yang menjadi pertimbangan awal adalah tentang kecukupan ekonomi. Besarnya biaya hidup untuk diri sendiri dan keluarga mengharuskan para subjek memenuhinya dengan berbagai cara.

Diakui atau tidak, alasan-alasan kesabaran tersebut muncul karena keterpaksaan. Mereka sadar bahwa ketika harapan hidup bahagia dengan keluarga tidak kunjung tercapai sehingga akan menjadi sumber stres yang sering menghasilkan perasaan kecewa, sakit hati dan kemarahan, maka sabar adalah satu-satunya solusi paling efektif untuk menghadapi semua.

\section{Daftar Pustaka}

Abu Yasid, 2005, Fiqh Realitas, Respon Terbadap Wacana Hukum Islam Kontemporer, Yogyakarta: Pustaka Pelajar.

Ahmad Musthafa Al-Maraghi, 1992, Tafsir al-Maraghi, terj. Bahran Abu Bakar, dkk. Semarang: Toha Putra.

al-Ghazali, 2004, Ringkasan Ibya' 'Ulum al-Din terj. Labib MZ, Surabaya: Bintang Usaha.

Al-Hamid, M. 2004. Kesalahan-Kesalahan Suami. Surabaya: Pustaka Progressif.

al-Qordhowi, Yusuf, 2006, Al-Qur'an Menyurub Kita Sabar, terj. Abdul Azis Salim Basyarahil, Jakarta: Gema Insani Press.

------. 2000. Anatomi Masyarakat Islam terj. Setiawan Budi Utomo, Jakarta: Pustaka Al-Kautsar.

------. 2002. Bagaimana Memahami Syari'at Islam terj. Nabhani Idris, Jakarta: Islamuna Press.

al-Thobary, Ibnu Jarir, Jami'al Bayan fi Tafsir al-Quran. juz 4. Beirut: Dar al-Fikr.

Andayani, B., 2001. Marital Conflict Resolution of middle Class Javanese Couples, Australia: La Trobe University. 
as-Shobuni, Ali, Rowai'ul Bayan Tafsir Ayatil Abkam Minal Qur'an. Beirut: Dar al-Fikr.

Aunur Rahim Faqih, 2001, Bimbingan dan Konseling dalam Islam, Yogyakarta: UII Press.

Davakisni, T. H, 2001. Psikologi Sosial. Malang: Penerbitan Universitas, Muhammadiyah Malang.

Depdikbud, 1990, Kamus Besar Bahasa Indonesia, Jakarta: Balai Pustaka. Fachruddin, 1992, Ensiklopedi Al-Qur'an. Jakarta: Rineka Cipta, jil. II, cet. I.

Hanna Djumhana Bastaman, 1995, Integrasi Psikologi dengan Islam (Menuju Psikologi Islam), Yogyakarta: Pustaka Pelajar.

Humaidi Tatapangarsa, Akblak Yang Mulia, Bina Ilmu: Surabaya.

Ibnu Q. Al Jauziyah, 2002, Sabar Perisai Seorang Mukmin, terj. Fadli, Jakarta: Pustaka Azzam.

-----. 2010. Indahnya Sabar. Terj. A.M. Halim. Maghfirah Pustaka: Jakarta.

Istibsyaroh, 2004, Poligami dalam Cita dan Fakta, Jakarta: Mizan Publika.

Jalaluddin Rahmat, 1998, Psikologi Agama, Jakarta: Rajawali Press.

Kartono, K, 1992. Psikologi Wanita. Bandung: Mandar Maju.

Koen, Z.. 2007. 40 Tanda dan 10 Alasan Laki-Laki Ingin Berpoligami. Yogyakarta: Penerbit Galang press.

Kutbuddin Aibak, 2006, Kajian Fiqh Kontemporer, Surabaya: eLKAF.

M. Shahrur, 2004, Metodologi Figh Islam Kontemporer, penj. Sahiron Syamsuddin dan Burhanuddin, Yogyakarta: eLSAQ Press.

Mas'ud Hasan Abdul Qohar. Kamus Ilmiah Populer. Jakarta: Bintang Pelajar.

Mubarak, S. I., 2003, Poligami yang Didambakan Wanita, Bandung: Syaamil Cipta Media. 
Muhyidin, M., 2003, Meraih Mabkota Pengantin, Kiat-Kiat Praktis Mendidik Istri dan Mengajar Suami, Jakarta: Lentera Basritama.

Musfir bin Said Az-Zahrani, 2005, Konseling Terapi, Jakarta: Gema Insani.

Najati, M. Usman, 2005, Psikologi dalam Al Qur'an. Bandung: Pustaka Setia.

Poerwandari, E. E., 1998, Pendekatan Kualitatif dalam Penelitian Psikologi, Jakarta: LPSP3 UI.

Subandi, 2011, Sabar: Sebuah Konsep Psikologi, Yogyakarta: Jurnal Psikologi UGM.

Ulya Ali Ubaid, 2012, Sabar dan Syukur, Jakarta: Amzah. 